$$
\text { CONF. } 960513-.13
$$

\title{
OPTIMIZATION OF TEXTURED-DIELECTRIC COATINGS FOR CRYSTALLINE-SILICON SOLAR CELLS
}

\author{
James M. Gee \\ Photovoltaic System Components Department \\ Sandia National Laboratories \\ Albuquerque, NM 87185-0752
}

\author{
Roy Gordon and Haifan Liang \\ Department of Chemistry \\ Harvard University \\ Cambridge, MA 02138
}

\begin{abstract}
We report on the optimization of textured-dielectric coatings for reflectance control in crystalline-silicon (c-Si) photovoltaic modules. Textured-dielectric coatings reduce encapsulated-cell reflectance by promoting optical confinement in the module encapsulation; i.e., the textured-dielectric coating randomizes the direction of rays reflected from the dielectric and from the $\mathrm{c}-\mathrm{Si}$ cell so that many of these reflected rays experience total internal reflection at the glass-air interface. Some important results of this work include the following: we demonstrated textured-dielectric coatings ( $\mathrm{ZnO}$ ) deposited by a highthroughput low-cost deposition process; we identified factors important for achieving necessary texture dimensions; we achieved solar-weighted extrinsic reflectances as low as $6 \%$ for encapsulated c-Si wafers with optimized textured-ZnO coatings; and we demonstrated improvements in encapsulated cell performance of up to $0.5 \%$ absolute compared to encapsulated planar cells with single-layer antireflection coatings.
\end{abstract}

\section{INTRODUCTION}

An obvious requirement for high efficiency in photovoltaic modules is low reflectance. Single-crystal silicon solar cells achieve very low reflectances through use of textured surfaces and antireflection coatings. Single-crystal silicon solar cells typically use (100) orientation, and the textured surface is obtained with an anisotropic chemical etch that etches (111) crystallographic planes much more slowly than the (100) planes. These etches typically use water, isopropyl alcohol, and either potassium or sodium hydroxide, and produce surfaces with foursided pyramids defined by the (111) planes [1]. The surface texture reduces reflectance by two methods: (1) many of the incident rays must intercept the surface at least twice before reversing directions; and (2) many of the reflected rays are trapped inside the module encapsulation due to total internal reflection at the glass-air interface (Fig. 1).

Anisotropic etches are less effective on multicrystalline-silicon ( $\mathrm{mc}-\mathrm{Si}$ ) substrates due to the random orientation of the crystalline grains [2]. Several techniques have been investigated for creating a textured surface on multicrystalline-silicon (mc-Si) solar cells, including electrochemical etching, chemical etching, and mechanical and laserscribe texturing of the mc-Si substrate [3-6]. Mechanical texturing and patterned chemical texturing have received the most attention to date for texturing mc-Si substrates.

We recently described a new technique for reducing the reflectance of photovoltaic modules using planar crystallinesilicon (c-Si) solar cells [7]. This new technique deposits an optically thick, dielectric coating with a large refractive index. $(n>2)$ and a textured surface on the $\mathrm{c-Si}$ solar cell. This textureddielectric coating (TDC) reduces encapsulated-cell reflectance by promoting optical confinement in the module encapsulation; i.e., the TDC randomizes the direction of rays reflected from the c-Si cell inside the module encapsulation, so that many of these reflected rays experience total internal reflection at the glass-air interface (Fig. 1). Our theoretical calculations found that TDC's were nearly as good as texturing silicon for reflectance control, and we experimentally demonstrated the TDC concept using diamond films deposited by chemical vapor deposition [7].

There are several potential advantages of TDC's compared to other methods for texturing mc-Si substrates directly. Firstly, the TDC deposition process should be less expensive compared to mechanical or patterned chemical texture processes. Secondly, the TDC deposition should be easier to implement with present c-Si commercial fabrication processes because the process works on planar cells and can be added at the end of the sequence with-

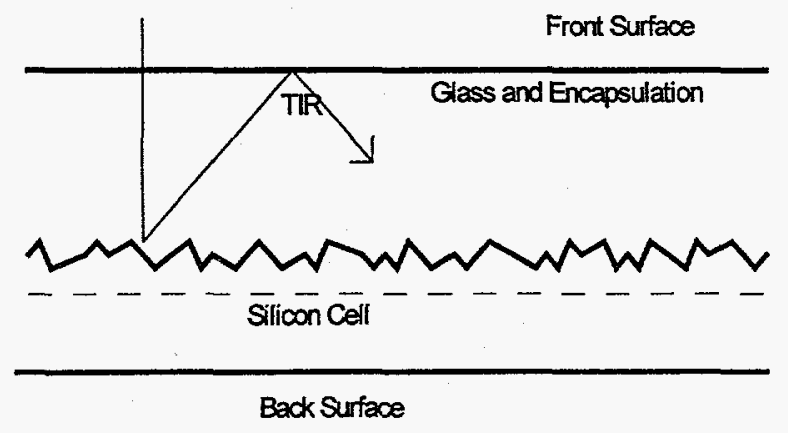

Fig. 1. Illustration of confinement of rays reflected from a textured surface inside a photovoltaic module due to total internal reflection (TIR) at the glass-air interface.

This work was performed by Sandia National Laboratories for the United States Department of Energy under contract DEAC04-94AL85000. 
out any changes to the rest of the process. The other texture processes produce textured surfaces early in the cell fabrication sequence; this textured surface can complicate some subsequent cell fabrication steps. Finally, the TDC process should be less damaging to the $\mathrm{C}-\mathrm{Si}$ substrate compared to mechanical texturing. Nevertheless, these economical and technical require a material with suitable optical properties (transparent and large refractive index), and an inexpensive, high-throughput deposition process that produces films with a textured surface.

In this paper, we report on optimization of textureddielectric coatings suitable for commercial production. The paper first discusses selection of materials for TDC's that could be deposited by a low-cost deposition technique. The paper then discusses optimization of the TDC deposition conditions for optimal geometry. Finally, the optimized coatings were applied to complete solar cells.

\section{EXPERIMENT}

The TDC requires the following properties: large refractive index $(n>2)$, low optical absorption between 0.35 and $1.2 \mu \mathrm{m}$, and a textured surface [7]. There has been considerable work on transparent conducting oxides (TCO) for thin-film photovoltaic modules. Some of the TCO materials investigated to date include tin oxide, indium tin oxide, titanium dioxide, and zinc oxide. These materials also have the appropriate optical properties for use as textured-dielectric coatings on c-Si solar cells, and can be deposited with high-throughput processes.

We investigated two materials: $\mathrm{TiO}_{2}$ and $\mathrm{ZnO}$. The coatings were deposited in a custom-fabricated belt-furnace atmospheric-pressure chemical vapor deposition (CVD) reactor. The reactor uses a Watkins-Johnson gas injection nozzle that allows separate injection of two different gases through $10 \mathrm{~cm}$ long parallel slots about $0.6 \mathrm{~cm}$ above the moving substrates. The $\mathrm{TiO}_{2}$ films were deposited at $450^{\circ} \mathrm{C}$ with titanium isopropoxide and water. The $\mathrm{ZnO}$ films were deposited at $250^{\circ} \mathrm{C}$ using water and diethylzinc. The lower deposition temperature for the $\mathrm{ZnO}$ is an advantage because it allows the films to be deposited over metal grids more easily. A disadvantage of $\mathrm{ZnO}$ is the relatively low refractive index (around 2), while the $\mathrm{TiO}_{2}$ films have a more optimal refractive index (around 2.2). The belt speed was 1 inch per minute; two passes of the substrate through the deposition zone produced films about $2-\mu \mathrm{m}$ thick. Thin films of $\mathrm{TiO}_{2}$ for antireflection coatings were deposited by electronbeam reactive evaporation.

The optical properties of the films were first optimized by depositing the films on polished silicon wafers. The hemispherical reflectance of the coated samples were measured both before and after encapsulation with a commercial spectrophotometer. The sample encapsulation was performed in a custom laminator, and used low-iron glass and EVA similar to commercial photovoltaic modules.

We fabricated a set of large-area $\left(42-\mathrm{cm}^{2}\right)$ cells with very uniform properties in the Photovoltaic Device Fabrication Laboratory (PDFL). These cells have planar surfaces and used 2$\Omega \mathrm{cm}$ float-zone (FZ) substrates. Half of these cells were then coated with optimized TDC films, and the cell performance was then measured both before and after encapsulation. High-quality processing and substrates were used for the experiment rather than commercial mc-Si cells in order to reduce statistical uncertainties in comparing control cells with coated cells. The cell characteristics (one-sun current-voltage and spectral response and reflectance) were measured both before and after encapsulation.

\section{RESULTS}

The $\mathrm{TiO}_{2}$ films were not adherent to the silicon wafers, and work with $\mathrm{TiO}_{2}$ was discontinued early. We therefore emphasized textured-ZnO coatings. We deposited $2-\mu \mathrm{m}$ thick, textured-ZnO films directly on silicon wafers and on silicon wafers with $\mathrm{TiO}_{2}$ antireflection coatings (ARC). Samples with $\mathrm{TiO}_{2}$ ARC's were included because the refractive index of $\mathrm{ZnO}$ is less than optimal for our TDC application. Figure 2 shows the as-deposited and encapsulated hemispherical reflectance of these samples, along with our theoretical fit. The theoretical fit used a
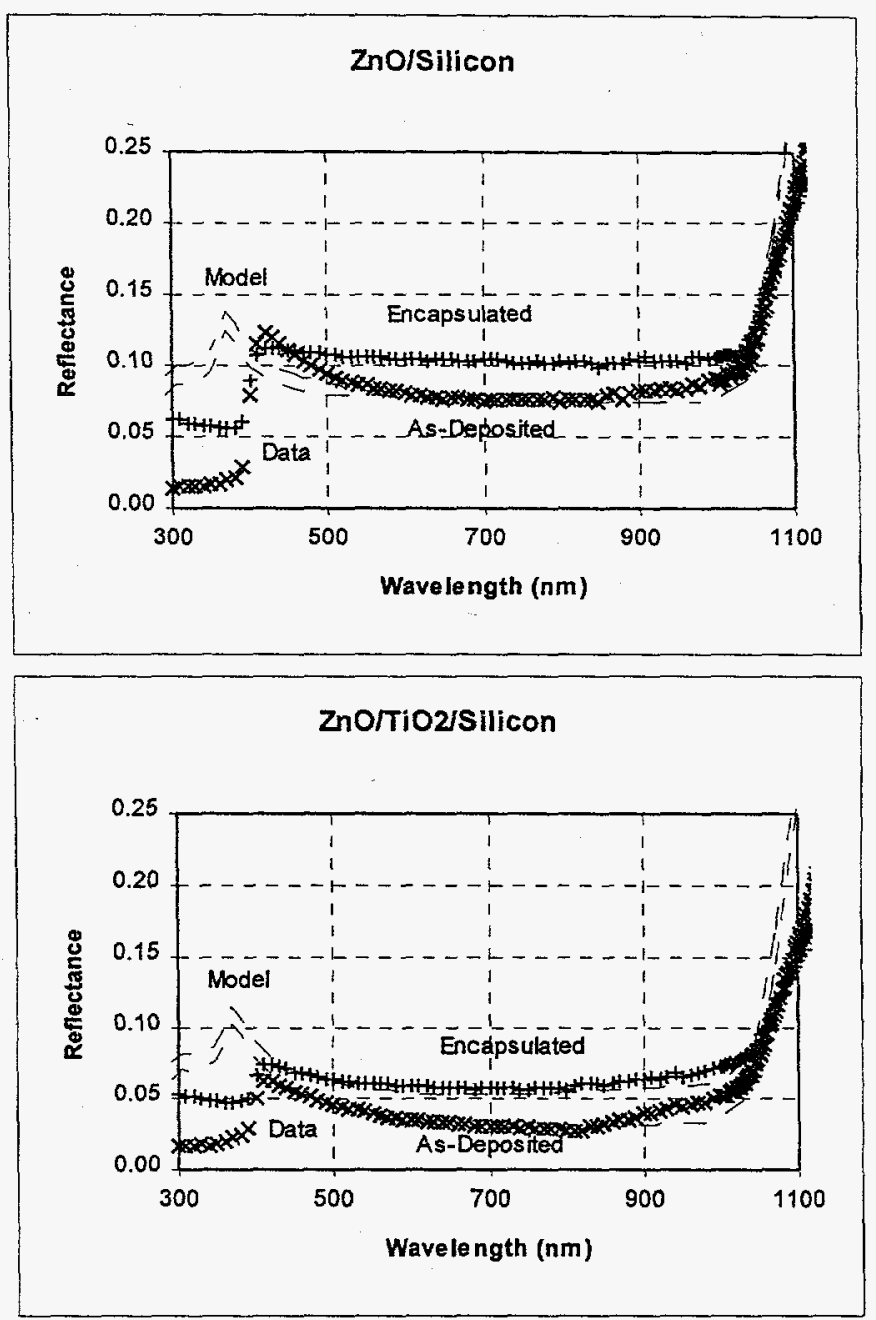

Fig. 2. Comparison of measured hemispherical reflectance (Data) and theoretical fits (Model) of as-deposited and encapsulated wafers with textured-ZnO coatings: textured$\mathrm{ZnO}$ deposited over silicon ( $\mathrm{ZnO} / \mathrm{Silicon}$ ), and textured- $\mathrm{ZnO}$ deposited over $\mathrm{TiO} 2$-coated silicon $\left(\mathrm{ZnO} / \mathrm{TiO}_{2} / \mathrm{Silicon}\right)$. There is a large discrepancy between Model and Data for short wavelengths ( $<400 \mathrm{~nm}$ ) because the model calculations do not include absorption in the optical coatings or in the encapsulant. 


\section{DISCLAIMER}

Portions of this document may be illegible in electronic image products. Images are produced from the best available original document. 



\section{DISCLAIMER}

This report was prepared as an account of work sponsored by an agency of the United States Government. Neither the United States Government nor any agency thereof, nor any of their employees, makes any warranty, express or implied, or assumes any legal liability or responsibility for the accuracy, completeness, or usefulness of any information, apparatus, product, or process disclosed, or represents that its use would not infringe privately owned rights. Reference herein to any specific commercial product, process, or service by trade name, trademark, manufacturer, or otherwise does not necessarily constitute or imply its endorsement, recommendation, or favoring by the United States Government or any agency thereof. The views and opinions of authors expressed herein do not necessarily state or reflect those of the United States Government or any agency thereof. 


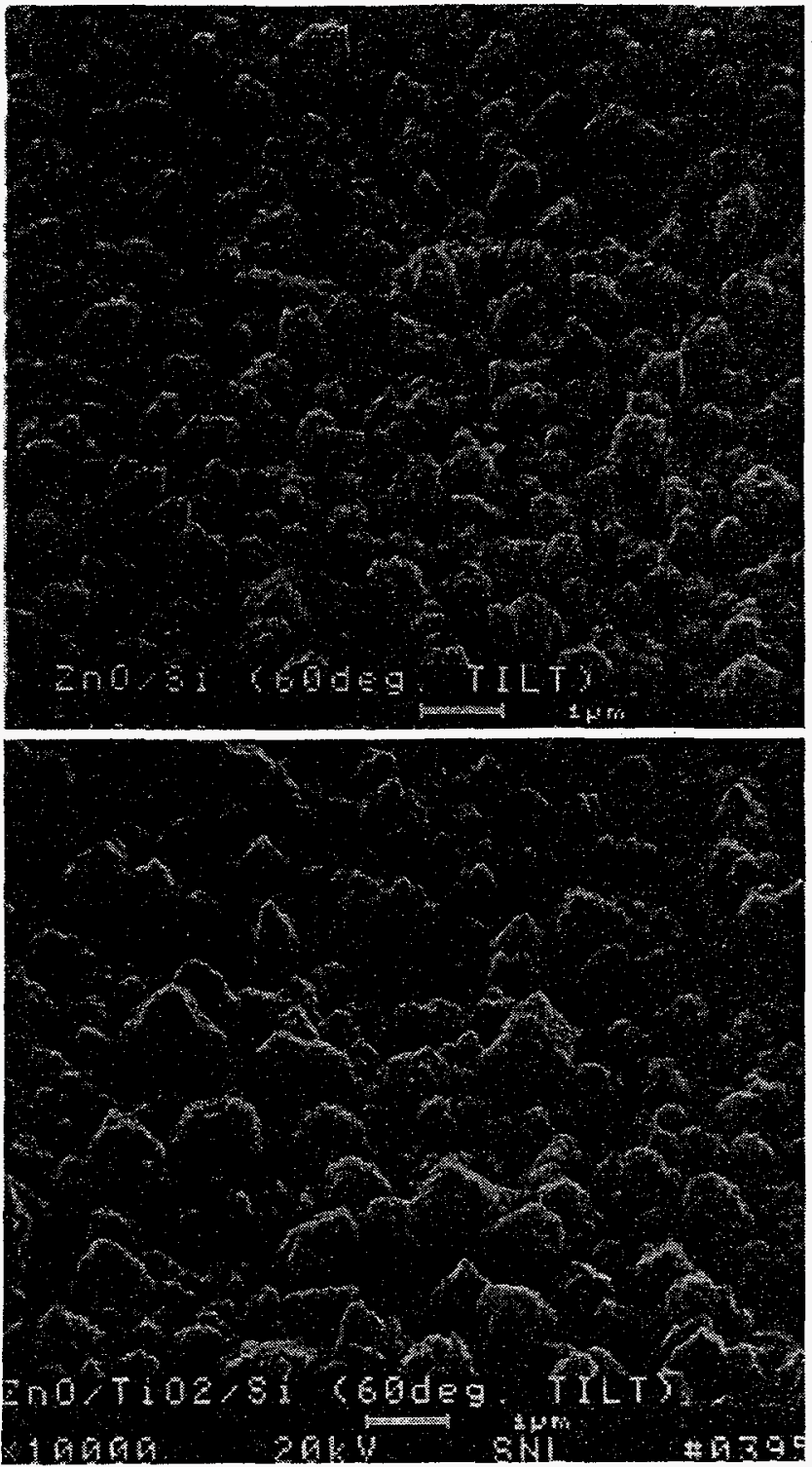

Fig. 3 SEM photomicrographs of textured-ZnO films deposited on silicon $(\mathrm{ZnO} / \mathrm{Si})$ and on $\mathrm{TiO}_{2}$-coated silicon $\left(\mathrm{Zn} / \mathrm{TiO}_{2} / \mathrm{Si}\right)$.

thick-film optical model of photovoltaic modules that was described previously [7]. The theoretical fit used published dispersion data for the $\mathrm{ZnO}$ [8]. The dispersion data for the $\mathrm{TiO}_{2}$ films was measured in our laboratory [9]. The only adjustable parameter in the model was the percentage of light reflected from the glass- $\mathrm{ZnO}$ interface that experienced double-bounce reflectance.

The reflectance of the $\mathrm{ZnO} / \mathrm{Si}$ sample actually increased after encapsulation and the theoretical fit was poor. The fit for the $\mathrm{ZnO} / \mathrm{TiO}_{2} / \mathrm{Si}$ samples was quite good and achieved encapsulated solar-weighted extrinsic reflectance's as low as $6 \%$. (Extrinsic reflectance only includes photons reflected from the front surface of the c-Si solar cell, and does not include weakly absorbed photons (wavelengths $>1000 \mathrm{~nm}$ ) reflected from the back surface of the c-Si solar cell.) The encapsulated solarweighted reflectance of $6 \%$ is a significant improvement compared to the present commercial process for $\mathrm{mc}-\mathrm{Si}$ photovoltaic modules, which use planar-surface silicon cells with a single-layer ARC and have encapsulated solar-weighted activearea reflectances around $9-12 \%$ [10]. The encapsulated solarweighted reflectance of the textured-ZnO samples also approach the value of encapsulated textured single-crystal silicon samples (around 5\%) [10].

An important element in the optimization of the TDC deposition is achieving sufficiently large texture dimensions for optical scattering. Scanning electron microscopy (SEM) photomicrographs show that both $\mathrm{ZnO} / \mathrm{Si}$ and $\mathrm{ZnO} / \mathrm{TiO}_{2} / \mathrm{Si}$ films exhibited columnar growth (Figure 3), which indicates that the texture dimensions are controlled by the initial nucleation of the deposition. The $\mathrm{ZnO} / \mathrm{Si}$ films were dense with a feature size around $0.5 \mu \mathrm{m}$, while the $\mathrm{ZnO} / \mathrm{TiO}_{2} / \mathrm{Si}$ films were more porous and had a feature size around $1 \mu \mathrm{m}$. The light scattering from the $\mathrm{ZnO} / \mathrm{Si}$ surface is not fully Lambertian (i.e., reflected rays do not fill $2 \pi$ hemisphere) over much of the solar spectrum due to the small feature size; the net result is that the encapsulated reflectance of the $\mathrm{ZnO} / \mathrm{Si}$ increased because fewer rays reflected from the cell were optically confined in the encapsulation. The larger texture dimensions of the $\mathrm{ZnO} / \mathrm{TiO}_{2} / \mathrm{Si}$ samples produced a more Lambertian scattering, which improved both the model fit and the optical performance.

The $\mathrm{TiO}_{2}$ ARC is not expected to be a problem in production because it can be deposited in the same belt- furnace CVD reactor with the textured- $\mathrm{ZnO}$ coating. Because the $\mathrm{TiO}_{2}$ film is necessary to obtain the proper texture dimensions, we performed a series of calculations to optimize the $\mathrm{TiO}_{2}$ films (Figure 4). These calculations also considered a thin $\mathrm{SiO}_{2}$ layer between the $\mathrm{TiO}_{2}$ film and the silicon surface; these thin $\mathrm{SiO}_{2}$ layers are commonly used for surface passivation. These calculations used a commercial ray-tracing program rather than our thick-optics model in order to include absorption in the thin films. The calculations indicate that a thicker $\mathrm{TiO}_{2}$ film is required than typically used for planar encapsulated cells.

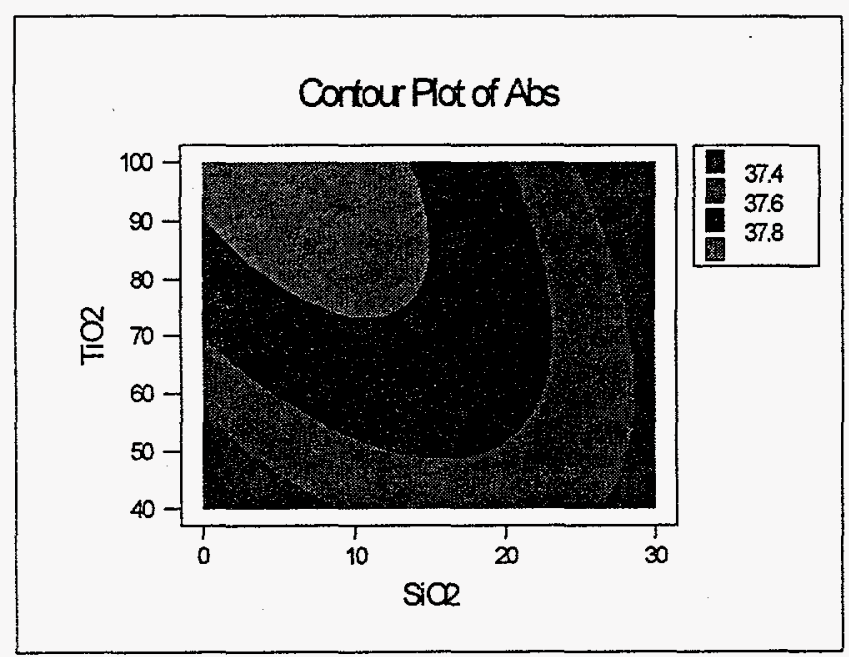

Fig. 4. Calculated solar absorptance (short-circuit current density with units of $\mathrm{mA} / \mathrm{cm}^{2}$ ) as a function of $\mathrm{TiO}_{2}$ and $\mathrm{SiO}_{2}$ thicknesses for encapsulated planar c-Si cells with a textured-ZnO coating. Calculations used a commercially available ray tracing program (Sunrays [11]). 


\section{CELL RESULTS}

We performed an experiment to confirm the optical advantages of TDC's for reflectance control in complete cells. We fabricated a set of $42-\mathrm{cm}^{2}$ cells on $\mathrm{FZ}$ silicon, deposited textured-ZnO on half of the cells, and encapsulated both the control and $\mathrm{ZnO}$-coated cells. Encapsulated cell performance is summarized in Table 1 and representative reflectance spectra is given in Fig. 5.

Table 1. Summary of IV characteristics for encapsulated planar cells. "Planar" cells have a $\mathrm{TiO}_{2} \mathrm{ARC}$, while $\mathrm{ZnO}$ cells have a textured- $\mathrm{ZnO}$ coating over the $\mathrm{TiO}_{2} \mathrm{ARC} .<\mathrm{R}>$ is solar-weighted reflectance, which is calculated from the measured reflectance spectra. The number of cells in the average is given in parenthesis.

\begin{tabular}{|ccccccc|}
\hline & & Eff & $\mathrm{V}_{\text {oc }}$ & $\mathrm{I}_{\text {Sc }}$ & FF & $\langle\mathrm{R}>$ \\
\hline Total & Avg. & 15.75 & 0.613 & 1.345 & 0.803 & 11.4 \\
$(12)$ & StD. & 0.35 & 0.002 & 0.023 & 0.005 & 2.6 \\
\hline Planar & Avg. & 15.55 & 0.612 & 1.332 & 0.800 & 13.8 \\
$(7)$ & StD. & 0.30 & 0.001 & 0.020 & 0.003 & 0.1 \\
\hline ZnO & Avg. & 16.03 & 0.614 & 1.363 & 0.807 & 9.1 \\
$(5)$ & StD. & 0.19 & 0.002 & 0.014 & 0.005 & 0.3 \\
\hline
\end{tabular}

The encapsulated $\mathrm{ZnO}$-coated cells have about a $0.5 \%$ absolute improvement in performance compared to the control cells. The improved performance was due entirely to $\mathrm{I}_{\mathrm{Sc}}$, which improved by about $2.3 \%$ due to the textured- $\mathrm{ZnO}$ coating. The $\mathrm{ZnO}$-coated cells also have a lower average solar-weighted

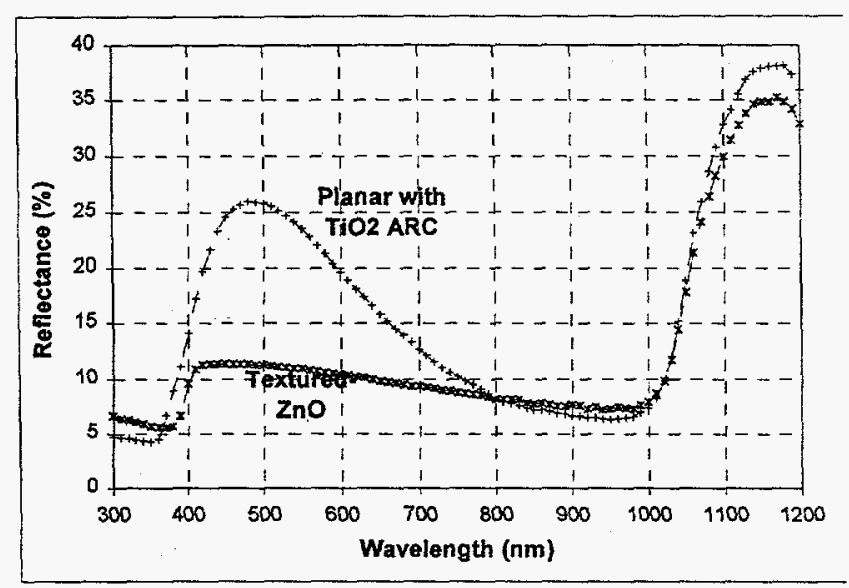

Fig. 5. Hemispherical reflectance spectra of encapsulated planar cells with and without textured- $\mathrm{ZnO}$ coating.

reflectance of around $9 \%$ compared to $14 \%$ for the encapsulated planar cells. The encapsulated cells with textured-ZnO coating have fairly flat spectral reflectance characteristics, and are dark gray in appearance. Note that the reflectance minima were at relatively long wavelengths, which indicates that the $\mathrm{TiO}_{2} \mathrm{ARC}$ was thicker than desired in these particular cells.

\section{CONCLUSIONS}

We presented results of a study to optimize textureddielectric coatings for reflectance control in photovoltaic modules. The study found that the coatings are quite effective optically, can be deposited with acceptable optical properties and with commercially relevant, high-throughput processes, and confirmed their performance advantages in complete encapsulated cells.

\section{ACKNOWLEDGEMENTS}

E. Buck, B. Silva, and J. Tingley fabricated the cells, L. Irwin and $\mathrm{K}$. Snyder performed the reflectance measurements and cell characterization, and T. Hund performed the cell tabbing and encapsulation.

\section{REFERENCES}

1. D.L. King and M.E. Buck, "Experimental Optimization of an Anisotropic Etching Process for Random Texturization of Silicon Solar Cells," 22nd IEEE PVSC, 1991, pp. 303308 (1991).

2. J.M. Gee et al., "The Effect of Encapsulation on the Reflectance of Photovoltaic Modules using Textured Multicrystalline-Silicon Solar Cells," Ist World Conf. on Photo. Energy Conv., 1994, pp. 1555-1558.

3. Y. S. Tsuo, et al., "Potential Applications of Porous Silicon in Photovoltaics," 23rd IEEE PVSC, 1992, pp. 287-293.

4. M.J. Stocks, J.J. Carr, and A.W. Blakers, "Texturing of Polycrystalline Silicon," 1st World Conf. on Photo. Energy Conv., 1994, pp. 1551-1554.

5. S. Narayanan, et al., " $18 \%$ Efficiency Polycrystalline Silicon Solar Cells," 21 st IEEE PVSC, 1990, pp. 678-680.

6. P. Fath, et al., "Mechanical Wafer Engineering for High Efficiency Solar Cells: An Investigation of the Induced Surface Damage," Ist World Conf. on Photo. Energy Conv., 1994, pp. 1347-1350.

7. J.M. Gee, R. Gordon, and H. Liang, "Reflectance Control for Multicrystalline-Silicon Photovoltaic Modules using Textured-Dielectric Coatings," 1st World Conf. on Photo. Energy Corv., 1994, pp. 1274-1277.

8. Brett and Parsons, Solid State Comm. 54, 604-606 (1985).

9. H. L. Tardy, Sandia National Laboratories, private communication.

10. J. M. Gee et al., "The effect of encapsulation on the reflectance of photovoltaic modules using textured multicrystalline-silicon solar cells," $1^{\text {st }}$ World Conf. on Photo. Energy Conv., 1994, pp. 1555-1558.

11. R. Brendel, "Sunrays: A Versatile Ray Tracing Program for the Photovoltaic Community," 12 th Eur. Photo. Sol. Energy Conf., 1994, pp. 1339-1342. 